\title{
Trichoderma and Clonostachys as biocontrol agents against Meloidogyne incognita in sacha inchi ${ }^{1}$
}

\author{
Kadir Márquez-Dávila², Luis Arévalo-López ${ }^{3}$, \\ Raúl Gonzáles ${ }^{3}$, Liliana Vega ${ }^{2}, \mathrm{Mario} \mathrm{Meza}^{4}$
}

\section{ABSTRACT}

One of the main pathological problems for cropping sacha inchi (Plukenetia volubilis L.) is its susceptibility to root-knot nematodes (Meloidogyne incognita). In this study, fungal endophytes were explored in the stems and leaves of seven species of the Plukenetia genus, and also evaluated the abilities of isolates of Trichoderma and Clonostachys as biocontrol agents against damages caused by this nematode in sacha inchi. In order to evaluate such effects, seedlings were colonized with these fungal isolates, and then they were infested with root-knot nematode eggs. The results showed that the Plukenetia genus is rich in diversity of fungal endophytes. Their greatest diversity was found in Plukenetia brachybotria. Among the most efficient isolates for endophytic colonization, some of Trichoderma (e.g., kmd-36 and kmd-54) and others of Clonostachys (e.g., kmd-68 and kmd-80) provided a significant $(\mathrm{p}<0.05)$ reduction in the number of galls induced by the nematodes, in comparison to the control treatment without endophytic colonization. In addition, these isolates allowed a better root development in the tested plants, thus revealing a good biocontrol potential against $M$. incognita in sacha inchi.

KEYWORDS: Plukenetia volubilis L., fungal endophytes, gall formation, root system.

\section{INTRODUCTION}

Sacha inchi (Plukenetia volubilis L.) has generated interest in the international market, in recent years, due to the fact that its seeds contain high levels of unsaturated fatty acids, proteins and vitamins A and E (Chirinos et al. 2013). Furthermore, it adapts to degraded soils and grows associated with leguminous species, improving the soil fertility and

\section{RESUMO}

Trichoderma e Clonostachys como agentes de biocontrole contra Meloidogyne incognita em sacha inchi

Um dos principais problemas patológicos para o cultivo de sacha inchi (Plukenetia volubilis L.) é sua suscetibilidade ao nematoide das galhas (Meloidogyne incognita). Nesta pesquisa, foram explorados fungos endofíticos em caules e folhas de sete espécies do gênero Plukenetia e avaliadas as habilidades de isolados de Trichoderma e Clonostachys como potenciais agentes de biocontrole contra danos causados por este nematoide em sacha inchi. Para avaliar tais efeitos, plântulas foram colonizadas com estes isolados fúngicos e, em seguida, foram infestadas com ovos do nematoide das galhas. Os resultados mostram que o gênero Plukenetia é rico em diversidade de fungos endofíticos. A maior diversidade deles foi encontrada em Plukenetia brachybotria. Entre os isolados mais eficientes para colonização endofítica, alguns de Trichoderma (e.g., kmd-36 e kmd-54) e outros de Clonostachys (e.g., kmd-68 e kmd-80) promoveram redução significativa $(\mathrm{p}<0,05)$ no número de galhas induzidas pelos nematoides, em comparação ao tratamento controle sem colonização endofítica. Ademais, estes isolados permitiram um melhor desenvolvimento radicular nas plantas testadas, revelando, assim, um bom potencial de biocontrole contra $M$. incognita em sacha inchi.

PALAVRAS-CHAVE: Plukenetia volubilis L., fungos endofíticos, formação de galhas, sistema radicular.

generating positive environmental impacts (Pezo et al. 2019, Solis et al. 2019).

Many species of plant-parasitic nematodes can act as pests on a wide range of important agricultural crops (Schouteden et al. 2015). The rootknot nematodes Meloidogyne incognita (Kofold \& White) Chitwood attack the root system of plants, inducing the formation of galls, reducing the root length and causing damages. In this way, they limit

1. Received: Oct. 24, 2019. Accepted: Apr. 03, 2020. Published: June 29, 2020. DOI: 10.1590/1983-40632020v5060890.

2. Universidad Nacional Hermilio Valdizán, Huánuco, Perú.

Email/ORCID: kmarquez@unheval.edu.pe/0000-0003-3019-5665, lvega@unheval.edu.pe/0000-0002-9692-0105.

3. Instituto de Investigaciones de la Amazonía Peruana, San Martín, Perú.

Email/ORCID: larevalo1@iiap.gob.pe/0000-0002-6417-8161,ragoal22@gmail.com/0000-0003-2914-9418.

4. Universidad Nacional Ciro Alegría, Huamachuco, La Libertad, Perú.

Email/ORCID: mario@mezahidalgo.com/0000-0001-9867-8298. 
and disrupt the transport of water and nutrients (Agrios 2005), being, therefore, considered a severe yield-limiting factor in the sacha inchi production (Márquez-Dávila et al. 2013). The indiscriminate use of chemical pesticides to control nematodes generates phytotoxicity and environmental pollution (Adegbite \& Adeyisan 2005); thus, practices for the control of nematodes are aimed at using chemical products with nemastatic effects. With the imminent removal from use of many effective nematicides, such as methyl bromide (Affokpon et al. 2011), due to an increasing concern about human health and the environment (Schouteden et al. 2015), the establishment of sustainable management alternatives for the control of root-knot nematodes has become an urgent need to improve yield. Cultural practices to control nematodes, such as the incorporation of organic amendments, crop rotation and use of plant traps, are not very effective; hence, biological control is a potential alternative.

Plants interact with microorganisms at all trophic levels, adapting growth, developmental and defense responses within a complicated network of community members (Yan et al. 2019). Studies about endophytic microorganisms of tropical plants are more frequent in recent years due to their potential for the biological control and production of compounds with pharmacological properties (Schouten 2016, Monteiro et al. 2017). Endophytes produce a wide range of compounds useful for plant growth, protection to environmental conditions and sustainability, in favor of a good dwelling place within the hosts (Nair \& Padmavathy 2014). The study and characterization of these microorganisms are important to discover new species and novel pharmacological compounds (Gutiérrez \& Estévez 2009), as well as to understand the plant-endophyte relationship (Arnold 2007). Trichoderma is a genus of free-living fungi that are common in soil and root ecosystems. The root colonization by these fungi frequently enhances the root growth, crop yield and resistance to abiotic stresses (Harman et al. 2004). In addition, Trichoderma plays a role as a biological control agent of fungi and nematodes (Martínez et al. 2013). On the other hand, some species of Clonostachys are parasites and antagonists of fungi, and of eggs and larvae of nematodes (Abreu et al. 2014).

There is a lack of studies about fungal endophytes of sacha inchi, although the practical aspects of endophytes, such as antibiosis, parasitism and colonization, have already been evaluated in other plant species (Harman et al. 2004, Bailey et al. 2008, Martínez et al. 2013). Studies like these are very important in the development of bio-protection strategies and, for this reason, the present study aimed to evaluate the abilities of isolates of Trichoderma and Clonostachys as potential biocontrol agents against damages caused by root-knot nematodes (M. incognita) in sacha inchi.

\section{MATERIAL AND METHODS}

This study was carried out at the Instituto de Investigaciones de la Amazonía Peruana, in San Martín, Peru $\left(6^{\circ} 35^{\prime} 28^{\prime \prime} \mathrm{S}, 7^{\circ} 18^{\prime} 47^{\prime \prime} \mathrm{W}\right.$ and altitude of 330 masl). For the isolation of fungal endophytes, tissues of seven Plukenetia species (Table 1) were collected. The plants were selected on the basis of four criteria, according to Hanada et al. (2010): 1) healthy appearance; 2) good nutritional status; 3) good physiological status; 4) free from any type of chemical and biological product application.

The targets for fungal endophyte isolates were tissues from stems $(8-\mathrm{cm}$ stem collected at $0.5 \mathrm{~m}$ above the soil level) and leaves (ten leaves without

Table 1. Political and geographical characterization of the locations where the collected species of the Plukenetia genus come from.

\begin{tabular}{|c|c|c|c|}
\hline Plukenetia spp. & Village & Political location & Geographical location $^{1}$ \\
\hline P. carolis-vegae & Monte alegre & Limabamba, Rodríguez de Mendoza - Amazonas & $6^{\circ} 35^{\prime} 89.2^{\prime \prime} \mathrm{S} ; 7^{\circ} 31^{\prime} 40.7^{\prime \prime} \mathrm{W} ; 1,726$ masl \\
\hline P. volubilis & Bello Horizonte & La Banda del Shicayo, San Martín - San Martín & $6^{\circ} 31^{\prime} 40.2^{\prime \prime S} ; 76^{\circ} 17^{\prime} 57.21^{\prime \prime} \mathrm{W} ; 572$ masl \\
\hline P. huayllabambana & Shucush & Longar, Rodríguez de Mendoza - Amazonas & $6^{\circ} 23^{\prime} 76.7^{\prime} \mathrm{S} ; 7^{\circ} 34^{\prime} 17.5^{\prime \prime} \mathrm{W} ; 1,617$ masl \\
\hline Plukenetia sp. & Shucush & Longar, Rodríguez de Mendoza - Amazonas & $6^{\circ} 23^{\prime} 76.7^{\prime \prime S} ; 7^{\circ} 34^{\prime} 17.5^{\prime \prime} \mathrm{W} ; 1,617$ masl \\
\hline P. brachybotrya & Puerto Almendra & San Juan, Maynas - Loreto & $3^{\circ} 49^{\prime} 35.5^{\prime \prime} \mathrm{S} ; 7^{\circ} 22^{\prime} 32.5^{\prime \prime} \mathrm{W} ; 105$ masl \\
\hline P. loretensis & Puerto Almendra & San Juan, Maynas - Loreto & $3^{\circ} 49^{\prime} 58.7^{\prime \prime} \mathrm{S} ; 7^{\circ} 22^{\prime} 42.9^{\prime \prime} \mathrm{W} ; 110$ masl \\
\hline P. polyadenia & Huitoto & Pebas, Ramón Castilla - Loreto & 320’04.9”S; 7155'12.3”'W; 101 masl \\
\hline
\end{tabular}

${ }^{1}$ masl: meters above the sea level 
mechanical damages or symptoms of disease; and three segments of tissue per leaf: lower, medium and upper segment), which were collected using a sterile scalpel. Small pieces of tissues of stems and leaves were disinfested with sodium hypochlorite $(1 \%)$ for one minute and rinsed with alcohol $(70 \%)$ and sterile distilled water. These tissues were transferred with sterile forceps to Petri dishes containing a standard culture media for fungi: potato dextrose agar (PDA) + $0.5 \mathrm{~g} \mathrm{~L}^{-1}$ of oxytetracycline. The samples were kept in a cooler $\left(22^{\circ} \mathrm{C}\right)$ until they were transferred to the laboratory and incubated at $25^{\circ} \mathrm{C}$ under darkness, for twenty days. Emerging colonies were sub-cultured and purified for single isolates. The fungal isolates were grown on Difco ${ }^{\mathrm{TM}}$ PDA medium and $\mathrm{BBL}^{\mathrm{TM}}$ cornmeal dextrose agar (CMDA) media, in Petri dishes, at $25^{\circ} \mathrm{C}$ under darkness, for twenty days. The morphological characteristics of each isolate (colony color, colony growth form, and presence or absence of halo) were registered during the growing of the colonies. Genera from each group were identified following specific taxonomic keys for fungi (Watanabe 2002), and then diversity was assessed using the Shannon index.

The potential for biological control of twenty isolates (ten of Trichoderma and ten of Clonostachys) was studied by determining their potential for endophytic colonization in sacha inchi roots and their antagonistic effects against root-knot nematodes. These isolates were selected according to preliminary studies carried out at the Instituto de Investigaciones de la Amazonía Peruana.

The selected fungal endophyte isolates were cultured in a PDA medium $+0.5 \mathrm{~g} \mathrm{~L}^{-1}$ of oxytetracycline for ten days, then sterile distilled water was added to the Petri dish with the endophyte fungus colony, and then the surface of the colony was removed with a glass rod to release the conidia from the mycelium. Conidial suspensions were diluted in a beaker with $80 \mathrm{~mL}$ of sterile distilled water and, using a pipette, $1.0 \mathrm{~mL}$ of a $1.0 \times 10^{6}$ conidial suspension of the endophytes (quantified in a Neubauer chamber) was inoculated per each $10 \mathrm{~g}$ of soil, using plastic trays (length: $0.10 \mathrm{~m}$; width: $0.10 \mathrm{~m}$; and height: $0.15 \mathrm{~m})$ with substrate $(2 / 3$ of agricultural soil and $1 / 3$ of earthworm humus) sterilized in an autoclave (Bailey et al. 2008).

To produce the seedlings, sacha inchi seeds were surface-sterilized by incubation in $2 \%$ sodium hypochlorite for five minutes, followed by three washes in sterile distilled water. In terms of seed orientation, the sterile seeds were sown with radicle tips pointed downwards inside the plastic trays previously prepared with sterile substrate and inoculated with the conidial suspension. The trays with seeds were placed into a micro-tunnel $(3.0 \mathrm{~m}$ long, $1.5 \mathrm{~m}$ wide and $0.6 \mathrm{~m}$ high) with a structure formed by a half-inch welded iron frame, placed horizontally and arched to form the micro-tunnel. The structure was lined with transparent polyethylene plastic. The base had an iron support and a metallic mesh to place the trays containing the substrates with the sacha inchi seeds. Likewise, the micro-tunnels had drains to avoid excessive water inside them. They were located into the greenhouse. The sacha inchi seeds grew for 45 days and were watered with sterile water when necessary.

A randomized complete block design was used, with 21 treatments (twenty isolates of fungal endophytes and one control treatment) and three blocks. In addition, in each block, ten sacha inchi seedlings per treatment were evaluated, totaling 630 sacha inchi seedlings for the evaluation of each variable.

To determine the endophytic ability of the fungal endophytes, the sacha inchi seedlings were dissected and stem disks were extracted. Then, thirty stem disks per treatment were plated in three Petri dishes with PDA medium $+0.5 \mathrm{~g} \mathrm{~L}^{-1}$ of oxytetracycline. They were incubated at room temperature (lab bench, $23{ }^{\circ} \mathrm{C}$ ) for five days and registered as positive $(+)$ if any growth of fungal endophytes was observed, or negative (-) if there was no apparent growth. Colonization rate is the proportion of tissues with endophytes, in relation to the total stem disks (Bailey et al. 2008).

The Meloidogyne species were identified based on the head shape and stylet morphology of males and the morphology of the perineal patterns of females (Hartman \& Sasser 1985, Cunha et al. 2018). Thus, although a precise identification of Meloidogyne species currently requires analysis at the molecular level, this was not done in this study.

$M$. incognita inoculum was multiplied in sacha inchi roots under greenhouse conditions. The roots were washed with tap water, cutting those with nodules into pieces of approximately $2 \mathrm{~cm}$, and then the roots were ground in a blender for three minutes, in one liter of water. The suspension was washed and sieved. The eggs and juvenile individuals (J2) of the 
M. incognita trapped in the 400-mesh sieve were collected and transferred to a $500-\mathrm{mL}$ precipitation glass (Jatala 1986). The inoculum was quantified with the help of a microscope, taking for this an aliquot of $5 \mathrm{~mL}$ of the suspension and transferring it to a Petri dish, finding around 50 eggs $\mathrm{mL}^{-1}$.

To evaluate the effect of endophytes on the biological control against root-knot nematodes, at ten days after the seedlings were colonized with fungal endophytes, they were inoculated with $10 \mathrm{~mL}$ of suspension containing around 500 eggs of $M$. incognita, at approximately $5 \mathrm{~cm}$ around the stem and $2 \mathrm{~cm}$ deep (Márquez-Dávila et al. 2013). The seedlings were grown into the micro-tunnels and watered when necessary, for 45 days, considering the life cycle of nematodes (Cepeda 1996). Then, the stem and root system of sacha inchi plants were separated and washed with water. The galls were stained with floxin B to facilitate the count. The number of galls per root was quantified, and the root length was determined using the Image Analysis Software for Plant Disease Quantification - ASSESS (Lamari 2002).

All data were registered in an Excel database. The analysis of variance was performed with normalized data and the means were compared with the Scott-Knott test at 0.05 of significance $(\alpha)$, using the statistical software InfoStat (Di Rienzo et al. 2014). Prior to the analysis of variance, the Shapiro-Wilk test ( $\alpha=0.05$ ) was performed to confirm the normality of the data. The count data were normal and, in the case of the percentage data, the original data were transformed into a $\log (\mathrm{x}+2)$, as recommended by Sheskin (2004).

\section{RESULTS AND DISCUSSION}

A total of 154 isolates of fungal endophytes were obtained from leaves (93 isolates) and stems
(61 isolates) of seven species of the Plukenetia genus, with the observed endophytic colonization being greater in leaves than in stems. In the Peruvian Amazon, Gazis \& Chaverri (2010) also analyzed sapwood as a source of endophyte isolates in Hevea brasiliensis (Willd. ex A. Juss.) Müll. Arg. trees and found that, as in the present study, the endophytic colonization frequency was greater in leaves than in sapwood. The identified isolates belong to the following genera: Clonostachys (32 isolates), Xylaria (33 isolates), Pestalotiopsis (31 isolates), Trichoderma (31 isolates), Botryosphaeria (14 isolates), Geotrichum (3 isolates), Penicillium (3 isolates), Phialophora (1 isolate), Fusarium (4 isolates) and Colletotrichum (2 isolates). The greatest diversity of fungal endophytes was observed in $P$. brachybotrya, with 26 isolates, 9 identified genera, and a Shannon Index equal to 1.80; whereas the smallest diversity was observed in $P$. polyadenia, with 10 isolates, 4 identified genera, and a Shannon Index equal to 1.28 (Table 2). Such diversity was influenced by the condition of the host plant, sampling time and the precise location of the sampling units (Unterseher 2011). Trichoderma and Clonostachys are two genera of fungal endophytes that have shown a biocontrol ability against rootknot nematodes in various crops (Harman et al. 2004, Herrera-Parra et al. 2018, Iqbal et al. 2018) and, because of this, both genera were selected to be assessed for their potential as biocontrol agents against the root-knot nematode $M$. incognita in sacha inchi.

The assays showed an inhibitory effect of the antagonistic strains on the number of galls induced by $M$. incognita. The isolates of Trichoderma and Clonostachys colonized the sacha inchi seedlings, and significant differences were found between the isolates of both fungal endophytes for the studied variables (colonization ability, number of galls and

Table 2. Diversity of fungal endophytes isolated from Plukenetia species.

\begin{tabular}{lccc}
\hline \multicolumn{1}{c}{ Plukenetia species } & Shannon index & Number of isolates & Number of genera \\
\hline P. brachybotrya & 1.80 & 26 & 9 \\
P. carolis-vegae & 1.29 & 25 & 5 \\
P. huayllabambana & 1.65 & 24 & 7 \\
P. loretensis & 1.53 & 33 & 6 \\
P. polyadenia & 1.28 & 10 & 4 \\
P. volubilis & 1.43 & 14 & 5 \\
Plukenetia sp. & 1.32 & 26 & 5 \\
\hline
\end{tabular}


root length) in the stem disk evaluation (Figures 1A and 1B). In the plants of the control treatment (without fungal endophytes), no colonization was found. Herrera-Parra et al. (2018) reported that three species of Trichoderma (T. harzianum, T. atroviride and $T$. virens) have the same potential as antagonistic agents against $M$. incognita, given that they reduce the gall formation and nematode reproduction. In the same way, Iqbal et al. (2018) demonstrated that Clonostachys rosea can control plant-parasitic nematodes, thereby improving the plant growth.

The Trichoderma isolate kmd-36 reduced significantly the gall formation in sacha inchi roots. The isolates kmd-54, kmd-62 and kmd-44 also showed good results in inhibiting the development of galls, and the isolate kmd-52 showed the highest number of galls (Figure 2A). In the case of Clonostachys isolates, kmd-68, kmd-80 and kmd-82 reduced significantly the gall formation in the roots, and the isolate kmd-84 showed the highest number of galls (Figure 2B). The development of more galls in the control plants (absence of fungal endophytes) indicates that Trichoderma and Clonostachys isolates contribute to reducing the gall formation.
Regarding the root length, there were significant differences between the isolates of both genera. The Trichoderma isolates kmd-59, kmd-36 and kmd-54 promoted a greater root growth in sacha inchi, when compared to the other isolates and the control treatment (Figure 3A). The Clonostachys isolates did not contribute to the growth of sacha inchi roots (Figure 3B). Root-knot nematodes affect the root system, inducing the formation of root galls (Márquez-Dávila et al. 2013), which are formed as a physiological disturbance in the root tissue, caused by female nematodes (Collange et al. 2011), hindering the absorption of water and nutrients by sprouts (Anjos et al. 2010) and reducing the root length (Márquez-Dávila et al. 2013), fruit size and yield (Anjos et al. 2010). The process of parasitism of root-knot nematodes is associated with the susceptibility of the plant, constant humidity in the soil, quality of inoculum and absence of natural enemies (Adegbite \& Adesiyan 2005). The Trichoderma and Clonostachys isolates inhibited the formation of galls in the roots of sacha inchi. However, it is worth noting that the best available knowledge of appropriate management practices and
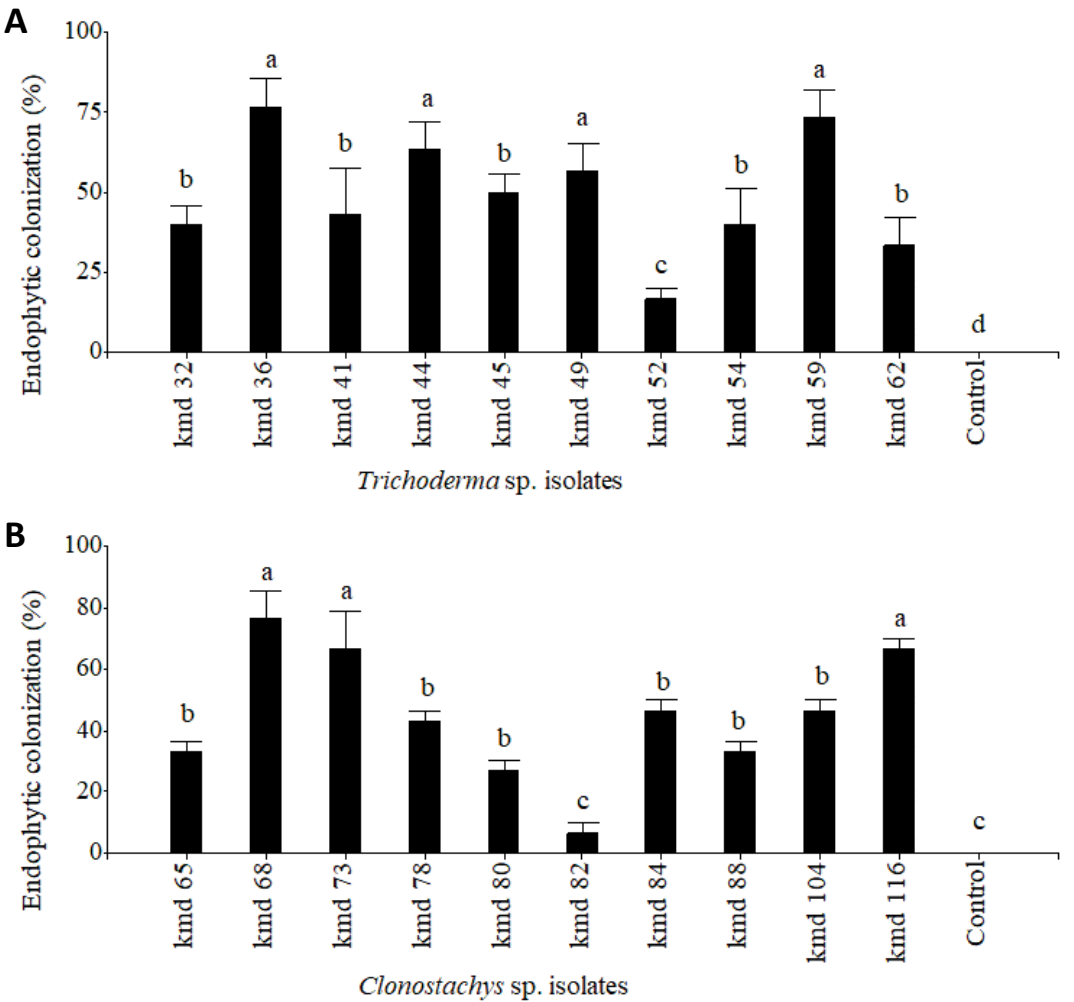

Figure 1. Colonization rates of Trichoderma (A) and Clonostachys (B) in sacha inchi seedlings. Bars with different letters indicate significant differences $(\mathrm{p}<0.05)$ between means by the Scott-Knott test. 

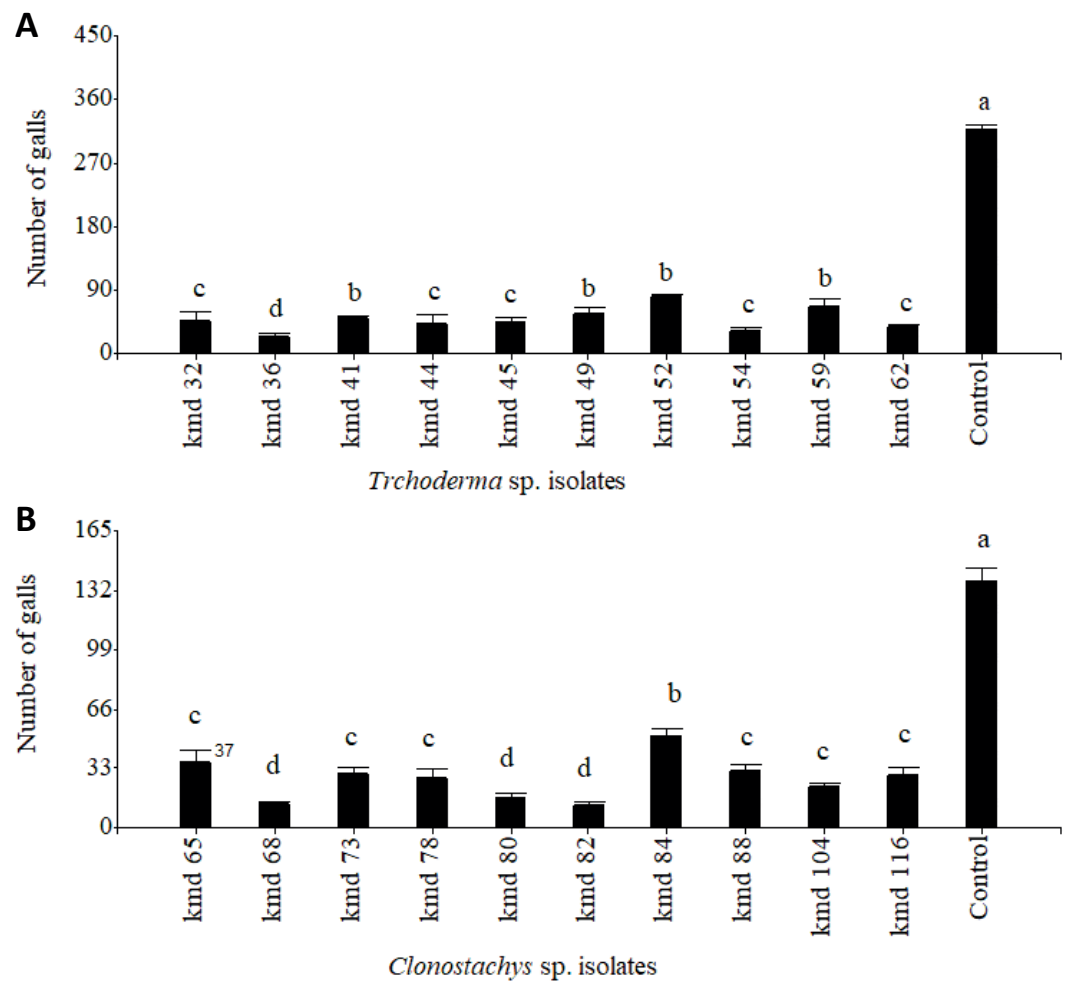

Figure 2. Number of galls on roots of sacha inchi seedlings, when colonized by Trichoderma (A) and Clonostachys (B). Bars with different letters indicate significant differences $(\mathrm{p}<0.05)$ between means by the Scott-Knott test.
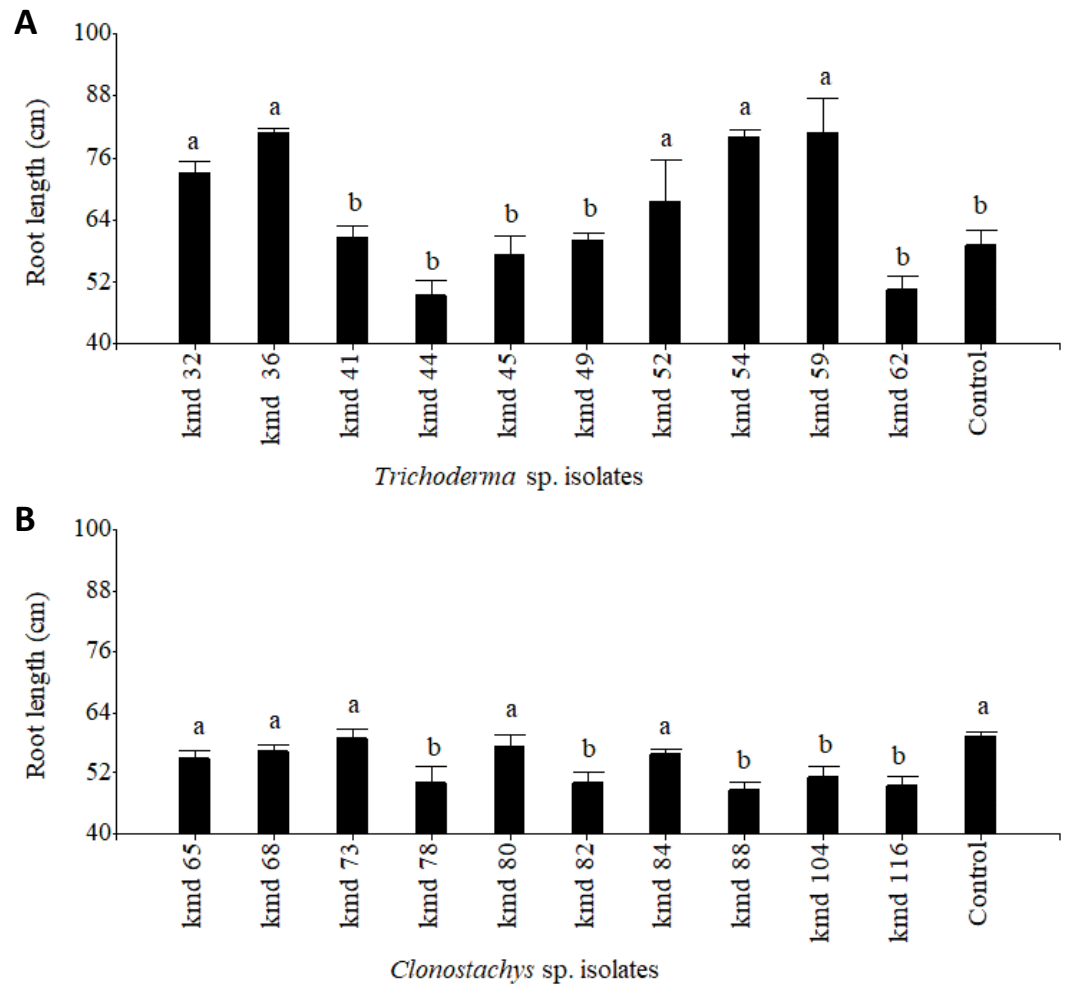

Figure 3. Root length in sacha inchi seedlings, when colonized by Trichoderma (A) and Clonostachys (B). Bars with different letters indicate significant differences $(\mathrm{p}<0.05)$ between means by the Scott-Knott test. 
responses to nematodes parasitism in sacha inchi is still limited.

Plants from tropical regions, in general, tend to harbor a larger diversity of endophytic microorganisms than those from temperate areas (Strobel \& Daisy 2003). Endophytes provide a special opportunity for exploring biological features of agricultural and environmental interests (Hanada et al. 2010). The diversity of fungal endophytes has been evaluated in tropical plants such as Hevea brasiliensis L. (Gazis \& Chaverri 2010), Theobroma cacao L. and T. grandiflorum (Willd. ex Spreng.) Schum. (Hanada et al. 2010). Fungal endophytes are biologically and taxonomically diverse (Mejía et al. 2008), and the great diversity of endophytes in P. brachybotria may be related to their capabilities of interaction with species of the Plukenetia genus, and also because they were collected in less disturbed areas. It is suggested that different species of Plukenetia could be inhabited by a great diversity of fungal endophytes which have an important biological activity.

A plant-associated habitat is a dynamic environment, in which many factors affect the structure and species composition of the microbial communities that colonize roots, stems, branches and leaves (Rubini et al. 2005). Besides, endophytic communities vary spatially in the plant or may be dependent on the interactions with other endophytes or pathogenic microorganisms (Bae et al. 2009). In our study, fungal endophytes from $P$. brachybotria and $P$. loretensis were collected in the same village, under the same environmental conditions, and showed different results. In P. brachybotria, the number of isolates was lower, but a greater diversity of endophytes was found in comparison to $P$. loretensis (Table 2). This is due to the fact that many endophytes in leaves are host, host genus or host family specific, and this specificity must depend on factors such as initial endophyte colonization and/ or substances within leaves and wood (Arnold 2007).

These endophytic microorganisms are ubiquitous and may increase the plant fitness by improving the tolerance to heavy metals and drought, reducing the herbivory or phytopathogen settling and promoting plant growth (Rubini et al. 2005). Several studies provide evidence to support the hypothesis that saprobe host specificity in plants is dependent on internal endophytes, while others indicate that host components may regulate the endophytes within (Paulus et al. 2006). This study provides basic information about the symbiosis between species of the Plukenetia genus and endophytic fungi for the development of effective biological control mechanisms against root-knot nematodes, the main limiting factor for the production of sacha inchi in the Peruvian Amazon.

The use of control methods that are more sustainable to treat plant diseases is a necessity in today's agriculture. From this perspective, the biological control of plant diseases emerges as an effective and viable alternative in the context of integrated management (Saraiva et al. 2014). Research on the biological control of plant diseases was intensified about thirty years ago, when it was realized that the biased use of chemical pesticides could have adverse effects on the environment, and that chemical residues could affect the quality and safety of food and feeding (Jensen et al. 2007). The endophytic niches of plants are a rich source of microbes that can directly and indirectly promote plant protection, growth and development (Hanada et al. 2010). Endophytes are considered inhabitants of soil and root colonizers (Harman et al. 2004), and, in recent years, they have gained importance as valuable natural resources for use in different areas, such as agriculture and biotechnology.

Trichoderma species, in general, grow fast, produce abundant conidia and have a wide range of enzymes, and it all allows them to inhabit almost all agricultural soils and other environments, demonstrating a great ecological plasticity (Martínez et al. 2013). There are isolates that are more efficient for the control of one pathogen than for another; for this reason, specificity must be evaluated (Martínez et al. 2008). Under in vivo conditions, the Trichoderma's competition in the rhizosphere was related to the colonization capacity of the root and adjacent space, with an important influence of factors such as soil type, $\mathrm{pH}$, temperature and humidity (Martínez et al. 2013). Harman et al. (2004) identified efficient strains of Trichoderma that colonized roots, and Bailey et al. (2008) characterized 15 isolates of Trichoderma that colonized roots, stems and leaves of T. cacao. Besides, Mihuta-Grimm \& Rowe (1986) showed that, of 255 isolates of Trichoderma obtained from different locations, only $15 \%$ were effective in controlling Rhizoctonia. Moreover, there are some species of Clonastachys, like C. rosea (Link) Schroers, Samuels, Seifert \& W. Gams, that act as a 
biocontrol agent against various plant pathogens, due to its antagonistic capacity to act as a hyperparasite, competing for nutrients and space, and inducing a plant resistance to pathogens (Carvalho et al. 2018). For example, $C$. rosea was found to be more efficient than fungicides in controlling Botrytis blight in strawberries in field trials (Cota et al. 2008).

Some members of these two genus, Trichoderma and Clonostachys, are significant biocontrol agents against plant pathogens by means of direct parasitism, competition with pathogens for nutrients, stimulator of plant health or by inducing a plant systemic resistance to pathogens (Bailey et al. 2006, Abreu et al. 2014). Trichoderma and Clonostachys isolates colonized roots (inoculation zone) and other tissues, and the results suggested that the association between sacha inchi and the diversity of endophytes play an integral role in regulating root-knot nematode damage and other diseases. The fact that some isolates of both Trichoderma and Clopnostachys show a better capacity to act as biocontrol agents could be explained, in part, by their use of two forms of antagonism: competition for space and nutrients and, more important, parasitism of hyphae, as reported in the case of C. rosea in Pinus radiata D. Don (Moraga-Suazo et al. 2011). The establishment of lasting endophytic associations in the root and shoot of sacha inchi may help to limit the number of chemical applications to control pathogens such as fungi and nematodes.

\section{CONCLUSIONS}

A great diversity of fungal endophytes may be found on the Plukenetia genus, mainly in the P. brachybotria species; some of them with abilities to colonize efficiently roots of sacha inchi (P. volubilis). Among these, some isolates of Trichoderma (e.g., kmd-36 and kmd-54) and Clonostachys (e.g., kmd-68 and kmd-80) were also able to reduce significantly $(p<0.05)$ the number of galls induced by the root-knot nematodes (Meloidogyne incognita). In addition, such isolates allowed a better root development in the plants, revealing to have a good biocontrol potential against damages caused by this nematode in sacha inchi.

\section{ACKNOWLEDGMENTS}

The authors thank the Programa Nacional de Innovación para la Competitividad y Productividad
(INNOVATE PERU), for the financial support to carry out this research.

\section{REFERENCES}

ABREU, L.; MOREIRA, G.; FERREIRA, D.; RODRIGUES-FILHO, E.; PFENNING, L. Diversity of Clonostachys species assessed by molecular phylogenetics and MALDI-TOF mass spectrometry. Fungal Biology, v. 118, n. 12, p. 1004-1012, 2014.

ADEGBITE, A.; ADESIYAN, S. Root extracts of plants to control root-knot nematode on edible soybean. World Journal of Agricultural Sciences, v. 1, n. 1, p. 18-21, 2005.

AGRIOS, G. Plant pathology. 5. ed. Cambridge: Academic Press, 2005.

ANJOS,É.C.T.; CAVALCANTE, U.M.T.; GONÇALVES, D. M. C.; PEDROSA, E. M. R.; SANTOS, V. F.; MAIA, L. C. Interactions between an arbuscular mycorrhizal fungus (Scutellospora heterogama) and the root-knot nematode (Meloidogyne incognita) on sweet passion fruit (Passiflora alata). Brazilian Archives of Biology and Technology, v. 53, n. 4 , p. 801-809, 2010.

ARNOLD, A. Understanding the diversity of foliar endophytic fungi: progress, challenges, and frontiers. Fungal Biology Reviews, v. 21, n. 1-2, p. 51-66, 2007.

BAE, H.; SICHER, R.; KIM, M.; KIM, S. H.; STREM, M.; MELNICK, R.; BAILEY, B. The beneficial endophyte Trichoderma hamatum isolate DIS $219 \mathrm{~b}$ promotes growth and delays the onset of the drought response in Theobroma cacao. Journal of Experimental Botany, v. 60, n. 11, p. 3279-3295, 2009.

BAILEY, B. A.; BAE, H.; STREM, M. D.; CROZIER, J.; THOMAS, S. E.; SAMUELS, G. J.; VINYARD, B. T.; HOLMES, K. A. Antibiosis, mycoparasitism, and colonization success for endophytic Trichoderma isolates with biological control potential in Theobroma cacao. Biological Control, v. 46, n. 1, p. 24-35, 2008.

BAILEY, B.; BAE, H.; STREM, M.; ROBERTS, D.; THOMAS, S.; CROZIER, J.; SAMUELS, G.; CHOI, I.; HOLMES, K. Fungal and plant gene expression during the colonization of cacao seedlings by endophytic isolates of four Trichoderma species. Planta, v. 224, n. 6, p. 14491464, 2006.

CARVALHO, A. L. A.; REZENDE, L. C.; COSTA, L. B.; HALFELD-VIEIRA, B. A.; PINTO, Z. V.; MORANDI, M. A. B.; MEDEIROS, F. H. V. de; BETTIOL, W. Optimizing the mass production of Clonostachys rosea by liquid-state fermentation. Biological Control, v. 118, n. 1, p. 16-25, 2018.

CEPEDA, S. Nematología agrícola. Ciudad de México: Editorial Trillas, 1996. 
CHIRINOS, R.; ZULOETA, G.; PEDRESCHI, R.; MIGNOLET, E.; LARONDELLE, Y.; CAMPOS, D. Sacha inchi (Plukenetia volubilis): a seed source of polyunsaturated fatty acids, tocopherols, phytosterols, phenolic compounds and antioxidant capacity. Food Chemistry, v. 141, n. 3, p. 1732-1739, 2013.

COLlANGE, B.; NAVARRETE, M.; PEYRE, G.; MATEILLE, T.; TCHAMITCHIAN, M. Root-knot nematode (Meloidogyne) management in vegetable crop production: the challenge of an agronomic system analysis. Crop Protection, v. 30, n. 10, p. 1251-1262, 2011.

COTA, L. V.; MAFFIA, L. A.; MIZUBUTI, E. S. G.; MACEDO, P. E. F.; ANTUNES, R. F. Biological control of strawberry gray mold by Clonostachys rosea under field conditions. Biological Control, v. 46, n. 3, p. 515$522,2008$.

CUNHA, T. G.; VISÔTTO, L. E.; LOPES, E. A.; OLIVEIRA, C. M. G.; GOD, P. I. V. Diagnostic methods for identification of root-knot nematodes species from Brazil. Ciência Rural, v. 48, e20170449, 2018.

DI RIENZO, J. A.; CASANOVES, F.; BALZARINI, M. G.; GONZALEZ, L.; TABLADA, M.; ROBLEDO, C. W. InfoStat: version 2014. Córdoba: Universidad Nacional de Córdoba, 2014.

GAZIS, R.; CHAVERRI, P. Diversity of fungal endophytes in leaves and stems of wild rubber trees (Hevea brasiliensis) in Peru. Fungal Ecology, v. 3, n. 3, p. 240254, 2010.

GUTIÉRREZ, A.; ESTÉVEZ, A. Relevancia de los productos naturales en el descubrimiento de nuevos fármacos en el S. XXI. Revista de la Real Academia de Ciencias Exactas, Fisicas y Naturales, v. 103, n. 2, p. 409-19, 2009.

HANADA, R.; POMELLA, A.; COSTA, H.; BEZERRA, J.; LOGUERCIO, L.; PEREIRA, J. Endophytic fungal diversity in Theobroma cacao (cacao) and T. grandiflorum (сириас̧u) trees and their potential for growth promotion and biocontrol of black-pod disease. Fungal Biology, v. 114, n. 1-2, p. 901-910, 2010.

HARMAN, G.; HOWEL, C.; VITERBO, A.; CHET, I.; LORITO, M. Trichoderma species-opportunistic, avirulent, plant symbionts. Nature Reviews Microbiology, v. 2, n. 1, p. 43-56, 2004.

HARTMAN, K. M.; SASSER, J. N. Identification of Meloidogyne species on the basis of differential host test and perineal pattern morphology. In: BARKER, K. R.; CARTER, C. C.; SASSER, J. N. (ed.). An advanced treatise on meloidogyne: volume II: methodology. Washington, DC: United States Agency for International Development, 1985. p. 69-77.
HERRERA-PARRA, E.; RAMOS-ZAPATA, J.; CRISTÓBAL-ALEJO, J.; TUN-SUAREZ, J.; REYESRAMÍREZ, A. Species of Trichoderma antagonistic to the root knot nematode (Meloidogyne incognita) in habanero pepper. International Journal of Experimental Botany, v. 87, n. 1, p. 7-13, 2018.

IQBAL, M.; DUBEY, M.; MCEWAN, K.; MENZEL, U.; FRANKO, M. A.; VIKETOFT, M.; JENSEN, D. F.; KARLSSON, M. Evaluation of Clonostachys rosea for control of plant-parasitic nematodes in soil and in roots of carrot and wheat. Phytopathology, v. 108, n. 1, p. 52$59,2018$.

JATALA, P. Biological-control of plant-parasitic nematodes. Annual Review of Phytopathology, v. 24, n. 1, p. 453-489, 1986.

JENSEN, D. F.; KNUDSEN, I. M. B.; LÜ BECK, M.; MAMARABADI, M.; HOCKENHULL, J.; JENSEN, B. Development of a biocontrol agent for plant disease control with special emphasis on the near commercial fungal antagonist Clonostachys rosea strain 'IK726'. Australasian Plant Pathology, v. 36, n. 2, p. 95-101, 2007.

LAMARI, L. ASSESS: image analysis software for plant disease quantification. St. Paul: APS, 2002.

MÁRQUEZ-DÁVILA, K.; GONZALES, R.; ARÉVALO, L.; SOLIS, R. Respuesta de accesiones de sacha inchi Plukenetia volubilis L. a la infestación inducida del nematodo Meloidogyne incognita (Kofoid and White, 1919) Chitwood 1949. Folia Amazonica, v. 22, n. 1-2, p. $97-103,2013$.

MARTÍNEZ, B.; INFANTE, D.; REYES, Y. Trichoderma spp. y su función en el control de plagas en los cultivos. Revista de Protección Vegetal, v. 28, n. 1, p. 1-11, 2013.

MARTÍNEZ, B.; REYES, Y.; INFANTE, D.; GONZÁLEZ, E.; BAÑOS, H.; CRUZ, A. Selección de aislamientos de Trichoderma spp. candidatos a biofungicidas para el control de Rhizoctonia spp. en arroz. Revista de Protección Vegetal, v. 23, n. 2, p. 118-125, 2008.

MEJÍA, L.; ROJAS, E.; MAYNARD, Z.; VAN BAEL, S.; ARNOLD, A.; HEBBAR, P.; SAMUELS, G.; ROBBINS, N.; HERRE, E. Endophytic fungi as biocontrol agents of Theobroma cacao pathogens. Biological Control, v. 46, n. 1, p. 4-14, 2008.

MIHUTA-GRIMM, L.; ROWE, C. Trichoderma spp. as biocontrol agents of Rhizoctonia damping-off of radish in organic soil and comparison of four delivery systems. Phytopathology, v. 76, n. 3, p. 306-312, 1986.

MONTEIRO, M. C. P.; ALVES, N. M.; QUEIROZ, M. V.; PINHO, D. B.; PEREIRA, O. L.; SOUZA, S. M. C.; CARDOSO, P. G. Antimicrobial activity of endophytic fungi from coffee plants. Bioscience Journal, v. 33, n. 2, p. 381-389, 2017. 
MORAGA-SUAZO, P.; OPAZO, A.; ZALDÚA, S.; GONZÁLEZ, G.; SANFUENTES, E. Evaluation of Trichoderma spp. and Clonostachys spp. strains to control Fusarium circinatum in Pinus radiata seedlings. Chilean Journal of Agricultural Research, v. 71, n. 3, p. 412-417, 2011.

NAIR, D. N.; PADMAVATHY, S. Impact of endophytic microorganisms on plants, environment and humans. The Scientific World Journal, v. 2014, e250693, 2014.

PAULUS, B.; KANOWSKI, J.; GADEK, P.; HYDE, K. Diversity and distribution of saprobic microfungi in leaf litter of an Australian tropical rainforest. Mycological Research, v. 110, n. 12, p. 1441-1454, 2006.

PEZO, M.; MÁRQUEZ-DÁVILA, K.; SOLIS, R. El ácido giberélico incrementa el rendimiento de plantas adultas de sacha inchi (Plukenetia volubilis). Scientia Agropecuaria, v. 10, n. 4 , p. 455-460, 2019.

RUBINI, M.; SILVA-RIBEIRO, R.; POMELLA, A.; MAKI, C.; ARAUJO, W.; SANTOS, D. dos; AZEVEDO, J. Diversity of endophytic fungal community of cacao (Theobroma cacao L.) and biological control of Crinipellis perniciosa, causal agent of witches' broom disease. International Journal of Biological Sciences, v. 1, n. 1, p. 24-33, 2005.

SARAIVA, R. M.; FRANÇA, P. E.; BORGES, Á. V.; MAFFIA, L. A. Uso e perspectiva de Clonostachys rosea como agente de biocontrole. Revista de Ciencias Agrícolas, v. 31, n. 1, p. 78-91, 2014.
SCHOUTEDEN, N.; WAELE, D. de; PANIS, B.; VOS, C. M. Arbuscular mycorrhizal fungi for the biocontrol of plant-parasitic nematodes: a review of the mechanisms involved. Frontiers in Microbiology, v. 6, e1280, 2015.

SCHOUTEN, A. Mechanisms involved in nematode control by endophytic fungi. Annual Review of Phytopathology, v. 54, n. 1, p. 121-142, 2016.

SHESKIN, D. Handbook of parametric and nonparametric statistical procedures. 3. ed. Oxford: Chapman \& Hall, 2004.

SOLIS, R.; PEZO, M.; ARÉVALO, L.; LAO, C.; ALEGRE, J.; PÉREZ, K. Evaluation of leguminous species as cover crops associated with sacha inchi. Pesquisa Agropecuária Tropical, v. 49, e58011, 2019.

STROBEL, G.; DAISY, B. Bioprospecting for microbial endophytes and their natural products. Microbiology and Molecular Biology Reviews, v. 67, n. 4, p. 491-502, 2003.

UNTERSEHER, M. Diversity of fungal endophytes in temperate forest trees. In: PIRTTILÄ, A.; FRANK, A. (ed.). Endophytes of forest trees: biology and applications. Dordrecht: Springer, 2011. p. 31-46.

WATANABE, T. Pictorial atlas of soil and seed fungi morphologies of cultured fungi and key to species. 2. ed. Boca Raton: CRC Press, 2002.

YAN, L.; ZHU, J.; ZHAO, X.; SHI, J.; JIANG, C.; SHAO, D. Beneficial effects of endophytic fungi colonization on plants. Applied Microbiology and Biotechnology, v. 103, n. 8, p. 3327-3340, 2019. 